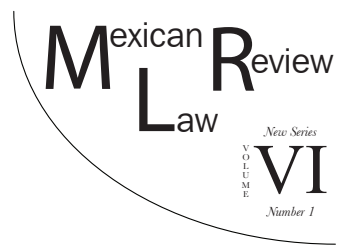

\title{
TRUTH AND VICTIMS' RIGHTS: TOWARDS A LEGAL EPISTEMOLOGY OF INTERNATIONAL CRIMINAL JUSTICE
}

\author{
Edgar R. AguilerA*
}

\begin{abstract}
The author advances the thesis that the now well established international crime victims' right to know the truth creates an opportunity for an applied epistemology reflection regarding international criminal justice. At the heart of the project lies the author's argument that this victims' right - if taken seriously - implies both the right that the international criminal justice system's normative structures or legal frameworks and practices feature a truth-promoting profile, or in other words, that they be designed, specified, and harmonized so as to enable the system as a whole to regularly lead to the formation of (fallible, though more likely) true beliefs about the world (both when it convicts and when it acquits); and a duty for the international community to implement the best epistemically-suited set of procedural and evidentiary rules and practices when it engages in the enterprise of engineering and setting in place international criminal tribunals, panels, chambers, or special courts. The author suggests that the research of the epistemologist Larry Laudan is quite relevant to the aims of the above project in that it outlines the general contours of a truth-promoting profile applicable to all instances of empirical systems of investigation. By contrasting Laudan's guidelines with the legal frameworks and practices of some international criminal tribunals, the author holds (though of course more research is needed) both that the victims' right to know the truth is being systematically transgressed at the international level in that these international institutions do not seem to possess an acceptable truth-promoting profile as one of their attributes; and that endowing them with such a profile is one of the ways in which the international community can pay its respects to victims' concerns.
\end{abstract}

* Ph.D in legal philosophy from the Institute for Legal Research of the National Autonomous University of Mexico, and certified in transnational legal studies by the Centre for Transnational Legal Studies, London. I am indebted to my University which awarded me with a scholarship to spend a research period at the Centre for Transnational Legal Studies where most of this article was written. Particularly, I wish to thank the Director of the Institute for Legal Research, Doctor Héctor Fix-Fierro, and Professor Imer B. Flores (who has a true vocation for the free discussion of ideas and a great passion for teaching) for all their support, guidance, and encouragement to engage in this work. 
Key Words: Applied epistemology, legal epistemology, victims' rights, truth and international criminal justice, epistemic principles and legal proceedings.

RESUMEN. El autor sostiene que el ahora bien establecido derecho a la verdad que tienen las víctimas de crimenes internacionales puede abrir la puerta para una reflexión epistemológica aplicada al terreno de la justicia penal internacional. En la base de dicha propuesta yace el argumento de que este derecho de las víctimas implica a su vez tanto el derecho a que los marcos jurídico-procesales y prácticas de los diversos tribunales penales internacionales exhiban un adecuado perfil veritativo-promotor o, en otras palabras, que dichos marcos y prácticas sean diseñados y armonizados de modo que confieran al sistema la habilidad de formar regularmente creencias (faliblemente) verdaderas acerca de los hechos que se alegan; como el deber de la comunidad internacional consistente en implementar el conjunto de reglas procesales más apto desde el punto de vista epistémico. Asimismo, el autor propone emplear las investigaciones del epistemólogo y filósofo de la ciencia Larry Laudan que delinean los componentes generales de un perfil veritativo-promotor óptimo, las cuales son, en principio, aplicables a todos los sistemas de investigación empírica. Habiendo contrastado los principios evaluativos sugeridos por Laudan con los marcos procesales y prácticas de algunos tribunales penales internacionales, el autor preliminarmente concluye que el derecho a la verdad de las víctimas está siendo violado a nivel internacional en virtud de que los tribunales respectivos no satisfacen los requerimientos de un perfil veritativo-promotor adecuado, y que conferir este perfil a los referidos tribunales constituye una forma en la que se respeta a las víctimas de atrocidades de carácter internacional.

Palabras Clave: Epistemología aplicada, epistemología jurídica, derechos de las víctimas, verdad y justicia penal internacional, principios epistémicos y procedimientos jurídicos.

TABLE OF CONTENTS

I. Truth and International Griminal LaW

1. The International Criminal Justice System as a Wide-Scale Response to Mass Atrocities....

2. The Key Features of the Multi-Purpose International Criminal Justice System

3. Main Thesis: Fact-Finding Accuracy (or an Adequate TruthSeeking Power) as the Core of the Criminal Justice System

4. Truth as a Legitimate Goal in its Own Right

5. Truth as a Fundamental Right of the Victims of International Crimes

6. The Victims' Right to Know the Truth and the International Community's Duty to Provide the Criminal Justice System with a Truth-Promoting Profile. 
7. An Outline of a Truth-Promoting Profile for the International Criminal Justice System (Based on Larry Laudan's Epistemic Principles)

II. The Pro-Conviction Bias

1. The International Criminal Tribunal for Yugoslavia (ICTY)..... 129

A. Lack of Evidentiary Gate-Keeping .....

B. Lack of Evidentiary Gate-Keeping and Hearsay Evidence... 131

C. The End-of-Orality Policy

D. Judicial Notice of Adjudicated Facts

E. Admission of Co-Accused Statements in Multi-Defendant Trials

F. ICTY's Plausible Motivations for Implementing TruthThwarting Patterns

G. Sumary.

2. The International Criminal Tribunal for Rwanda (ICTR), Special Court for Sierra Leona (SCSL), and the Special Panels for East Timor (Nancy Combs' Findings)

A. The Prevalence of Eye-Witness Testimony at these Tribunals.

B. General and Contextual Caution Regarding Eye-Witness Testimony

C. The Nature of Testimonial Deficiencies

D. Unconveyed Information

E. Problems Arising from Unconveyed Information

F. Innocent-Causes of Testimonial Deficiencies

G. Non-Innocent Causes of Testimonial Deficiencies (Systematic Perjury)

H. High Conviction Rates at these International Tribunals ....... 152

I. Trial Chambers' Attitude Towards Testimonial Deficiencies.

J. Explaining the Pro-Conviction Bias

K. A Plausible Alternative Model for the Trial Chambers Action

L. Plausible Motivations for the Implementation of a Surreptitious Fact-Finding Model 


\section{Truth and International Griminal LaW}

\section{The International Criminal Justice System as a Wide-Scale Response to Mass Atrocities}

In "one of the more extensive waves of institutional-building in modern international relations," the international community has orchestrated a wide-scale response to what has become, mostly after the end of World War II, humankind's constant companion. By that I mean the abuse of public power.

In effect, throughout 250 post-WWII conflicts around the globe, State/ Government-sponsored violence has metastasized leaving in its way a black trail of suffering and destruction for an estimated 70 to 170 million victims ${ }^{2}$ who have been subjected to a host of "unimaginable atrocities that deeply shock the conscious of humanity," such as "genocide," "crimes against humanity," and "war crimes."

Following decades of inaction since Nuremberg trials, an international wide-scale response helped create new legal institutions ${ }^{7}$ that facilitated the rise of an international criminal justice system. In the coming years, this structure shall be likely improved, especially considering its relatively early stage of development.

1 See Mark A. Drumby, Atrocity, Punishment, and International Law 10 (2007) cited by Nancy Combs, Fact-Finding Without Facts. The Uncertain Evidentiary Foundations of International Criminal Convictions, 1 CAmbridge, 2010.

${ }^{2}$ See Marcus Funk, Vigtim's Rights and Advocacy at the International Criminal Court 1 (Oxford University Press). The author adds that "experts estimate that during the twentieth century, warlords and military leaders subjected approximately four times more civilians to crimes against humanity and war crimes than the combined total of soldiers killed in all international wars during the same time."

3 See Rome Statute of the International Criminal Court Preamble, Jul. 17, 1998.

${ }^{4}$ See id. Art. 6 (a) to (e); Statute of the International Criminal Court for the former Yugoslavia (ICTY) Art. 4; and the Statute of the International Criminal Court for Rwanda (ICTR) Art. 2.

${ }^{5}$ See Rome Statute of the ICC Art. 7; "Elements of Crimes", Art. 7 para. 1; Statute of the ICTY Art. 5; and Statute of the ICTR Art. 3.

${ }^{6}$ See Rome Statute of the ICC Art. 8; the "Elements of Crimes" Art. 8 para. 2; the Statute of the ICTY Art. 3; and the Statute of the ICTR Art. 4.

${ }^{7}$ Such as the International Criminal Court for the former Mugoslavia (ICTY), http://www.icty. org/; International Criminal Tribunal for Rwanda (ICTR), http://www.unictr.org/; Special Court for Sierra Leone (SCSL), http://www.sc-sl.org/, the Special Panels in the Dili District Court In East Timor (Special Panels), http://wn.com/Special_Panels_of_the_Dili_District_Court; Extraordinary Chambers in the Courts of Cambodia (ECCC), http://www.eccc.gov.kh/en; Special Tribunal for Lebanon (STL), http://www.un.org/apps/news/infocus/lebanon/tribunal/; and ultimately a permanent International Criminal Court (ICC), http://www.icc-cpi.int/Menus/ICC. 


\section{The Key Features of a Multi-Purpose International Criminal Justice System}

Perhaps with more enthusiasm than realism, this international justice system is believed to warrant the realization of a wide range of different purposes, values or interests. ${ }^{8}$ As Nancy Combs points out, some of those are:

A) To affirm the rule of law in previously lawless societies;

B) To promote peace building and transition to democracy in war-torn lands;

C) To assist in reconciling former enemies;

D) To deter future megalomaniacs from committing similar crimes;

E) To create a historical record of the conflict; and

F) To diminish the victims' propensity to blame collectively all those in the offenders' group. ${ }^{9}$

\section{Main Thesis: Fact-Finding Accuracy (or an Adequate Truth-Seeking Power) as the Core of the Criminal Justice System}

I submit that meeting the above ends depends crucially (though not exclusively) on the system's ability to make sufficiently accurate factual determinations. Accordingly, establishing (of course fallibly) the truth of what happened $^{10}$ (solving the main conundrum of who did what to whom) constitutes a necessary solid basis which we would have to secure if achieving those other goals in not just wishful thinking.

As Combs observes, the problem is that the ability of international criminal tribunals (e.g., ICTY, ICTR, etc.) to accurately assess the facts of cases brought before them has been taken for granted with little suspicion by both legislators and academics. ${ }^{11}$ It is as if this epistemic ability could simply just pop out to the surface regardless of whatever rules of procedure and evidence that have been laid down; or as if those rules had already reached the pinnacle of their epistemic evolution, hence leaving no room for their constant revision (and reform if needed).

${ }^{8}$ See Combs, supra note 1, at 2-10, 186-188.

${ }^{9}$ Id. at 1 .

${ }^{10}$ It has been a while since the empiricist philosophers made a powerful case that any human inquiry into the past, present or future characteristics of events that unfold in this world can aspire at best, to establish their findings to a "moral certainty" (propositions-conclusions that though subject to the eternal challenge of the sceptic may be considered as well-grounded beliefs supported by multiple lines of argumentation each one of them in deed very weak if considered in isolation, but providing sufficient evidentiary or probatory weight as a whole). Absolute certainty is the province, if any, of mathematics, and more broadly, of deductive logics where principles such as non-monotonicity, and the criteria of soundness coupled with validity, apply to deductive arguments. That is why I referred to the establishment of the truth as a fallible or defeasible enterprise (the shadow of error is permanent despite our best efforts to reduce it).

11 See Combs, supra note 1. 
But having an epistemically well-suited criminal justice system is not as free of charge as it is usually thought of. In order for criminal justice institutions and proceedings (both, at the international and at the national levels) to perform and deliver as the epistemic engines they purport to be, deliberate measures have to be put at place. This is the main idea driving this work. ${ }^{2}$

Before we discuss how we should endow criminal justice systems with an acceptable truth-seeking power, let us review the arguments in support of the objective of establishing the truth that portray it as a value in its own right, and as an essential feature of international crime victims' concerns and rights.

\section{Truth as a Legitimate Goal in its Own Right}

Establishing the truth of the matters brought before the courts has been regarded as a valuable goal of criminal justice in its own right (independently of the fact that if satisfied it may boost the probabilities that other ends are achieved). Thus, it is said that truth is an indispensable component of a just verdict. Furthermore, from a more general stance it has been also argued that establishing the truth contributes to legitimizing adjudication as an adequate means for dispute resolution, and to the justification of the assumption (and expectation) that law guides the citizenry's conduct; and to the citizenry's motivation to keep obeying the law.

\section{Truth as a Fundamental Right of the Victims of International Crimes}

Apart from being a necessary condition pursuant to the promotion of other ends, and a legitimate goal in itself to be achieved by a criminal justice system (whether national or international), truth plays a crucial role as a corollary of the progressive development that the international crime victims' doctrine has experienced throughout the $20^{\text {th }}$ and $21^{\text {st }}$ centuries in humanitarian law, international human rights law, and finally in international criminal law (particularly in the ECCC, and the ICG): Victims, it is now well-established, have a "right to know the truth."

Marcus Funk (a leading commentator of the ICC's framework for victim participation) refers to the rationale behind this right as follows:

...survivors of atrocity crimes, as well as the families and loved ones of those who were injured or murdered, want to know first and foremost what hap-

${ }^{12}$ Which is inspired by the groundbreaking research of Larry Laudan. See LarRy Laudan, Truth, Error, and the Criminal Law. An Essay in Legal Epistemology (Cambridge University Press, 2006).

13 See William A. Schabas, An Introduction to the International Griminal Court 326, 327 (Cambridge University Press, 2010); see also FunK, supra note 2, at 29-41. 
pened, who committed the crimes, and why the crimes were committed... Victims seek the truth because the truth, to some extent at least, alleviates their anguish, vindicates their status, encourages individual accountability, and has the potential of removing the perpetrators and their allies from power... [Establishing the truth] makes it more difficult for those accused to create fictionalized, self-serving accounts of what occurred. A proper understanding of the historic events, and even public outrage over the conduct that often took place in the public's name, can replace the twin dangers of complacency and resentment towards victims. ${ }^{14}$

International criminal justice rulings also recognize the victims' right to truth. For example, the Pre-Trial Chamber of the ECCG has authoritatively opined that apart from generally supporting the prosecutor and making reparation claims, a main reason for victims to participate in the proceedings stems from two core rights - the right to the truth, and the right to justice..$^{15}$

For its part, the Pre-Trial Chamber I of the ICC has acknowledged that in addition to security and privacy, other interests of victims may include the interest in the determination of the facts, the identification of those responsible and the declaration of their responsibility, ${ }^{16}$ and that "the victims' central interest in the search for the truth can only be satisfied if (i) those responsible for perpetrating the crimes for which they suffered harm are declared guilty, and (ii) those not responsible for such crimes are acquitted, so that the search for those who are criminally liable can continue." ${ }^{\prime 17}$

The above reference to ECCG and ICG case-law may lead us to think that the only appropriate (and even necessary) instrument to establish the truth of what happened is by way of implementing criminal proceedings (whether inquisitorial, adversarial, or some sort of mixture of both modalities). But even if we assume that an accurate determination of what occurred is the most frequent outcome of adversarial, inquisitorial or mixed criminal proceedings this does not exclude the possibility that truth be also obtained by means other than (or in combination with) the implementation of the previously mentioned traditional criminal law structures. Amnesty-based truth commissions and State panels figure as some of the options, though of course, there is no definitive recipe. ${ }^{18}$

14 See Funk, supra note 2, at 127.

15 See Karim A., Dixon, R., Archbold International Griminal Courts; Practice, ProGedure, And Evidence 1142 (Sweet and Maxwell, 2009).

${ }^{16} I d$. at 1141 .

${ }^{17} \mathrm{Id}$.

18 See Tricia D. Olsen et al., When Truth Commissions Improve Human Rights, 4 The International Journal of Transitional Justice 457-476, 2010; Gearoid Millar, Assessing Local Experiences of Truth-Telling; Getting to 'Why? Trough a Qualitative Case Study Analysis, 4 The InternationaL Journal of Transitional Justice 477-496, 2010; and Oskar N. T. Thoms et al., State-Level Effects of Transitional fustice: What Do We Know?, 4 The InTERnational Journal of Transitional Justiae 329-354, 2010. 
Accordingly, the victims' right to truth may have (at least) two readings: The first is a very abstract one in the sense of being independent of the particular combination of mechanisms and institutions set forth to advance this goal. ${ }^{19}$

For its part, the second less abstract reading of the victims' right to truth - specifically related to the implementation of criminal justice proceedings as a response to widespread violence - would imply the right that the system's structure, practices and cognitive processes carried out by its operators have a truth-promoting profile (whether the system concerned is the ICTY, ICTR, ECGC, ICG or any other), or in other words, that those legal normative structures, practices and cognitive processes be designed, specified, and harmonized in a manner that enables the system to regularly lead to the formation of (fallible, though more likely) true beliefs about the world (both when it convicts and when it acquits).

\section{The Victims' Right to Know the Truth and the International Community's Duty to Provide the Criminal Fustice System with a Truth-Promoting Profile}

The flip side of this implied right - if it is to be effectively implementedwould be a very general duty or obligation for the international community on the one hand, to seriously include in the agenda the problem of conferring a truth-promoting profile (as opposed to just simply take it for granted) when it goes about engineering and setting in place international criminal tribunals, panels, chambers, or special courts; and on the other hand, to keep monitoring their performance due to the systems' arguably inherent tendency to take (a may be huge) distance from the originally established legal framework once they start operations (as will be shown below), and because no truth-promoting profile is definitive (there is no fixed formula - though some general principles may be established - as to the adequate and everlasting epistemic or truth-conducive particular content of the rules of evidence and procedure

${ }^{19}$ In this respect we may say that a second order truth-related right emerges for the victim which consists of the right to the determination of the most effective and convenient steps to be taken as a response to post-conflict situations. This second-order right would take into account not only the interest for the truth but also the implementation of suitable protective measures on behalf of the victims, how to better meet reparation and compensation claims, the previously mentioned overall interest of the community in reconciliation, and the like. The spirit of this overarching right (which implies that sometimes the triggering of criminal proceedings might not be the better option) runs through the ICC Rome Statute which in its article 53, 1, (c) entrusts the Prosecutor with the task of determining - once he has established that there are reasonable basis for believing that a crime within the jurisdiction of the Court has been or is being committed and that it is or would be admissible - whether to initiate an investigation "would not serve the interests of justice", considering the gravity of the alleged crimes and the interests of victims. 
which jointly provide the core of the normative structure of a criminal justice system).

\section{An Outline of a Truth-Promoting Profile for the International Criminal Fustice System (Based on Larry Laudan's Epistemic Principles)}

What would a truth-promoting profile be like? The research of the epistemologist and philosopher of science Larry Laudan is relevant to this point. He has proposed a theoretical framework to scrutinize the epistemic virtues and shortcomings of criminal justice systems, especially in relation to how the US criminal justice system ranks in terms of truth-conduciveness. ${ }^{20}$

The point of departure for what the author calls the "hardcore" part of his proposal is a thought experiment that captures the main features of an optimal truth-conducive criminal justice system (one which at this initial stage intentionally suppresses other factors) as a basic principles that help determine the content of rules of evidence ${ }^{21}$ and rules of procedure ${ }^{22}$ in all criminal justice systems.

One such principle (p1) that serves as a guideline for rules (and practices) of evidence-admission, states that:

(p1) "The triers of fact — whether jurors or judges in a bench trial — should see all (and only) the reliable, non-redundant evidence that is relevant to the events associated with the alleged crime." ${ }_{23}$

For its part, the following principle (p2) applies to rules of procedure:

20 See LaUdan, supra note 12.

${ }^{21}$ Laudan stipulates that the rules of evidence establish what evidence the fact-finder - jury, judge or body of judges - will encounter. See id. at 141.

${ }^{22}$ For its part, the rules of procedure establish the details of when and how the fact-finder becomes aware of the evidence admitted. Nonetheless, they go much further than simply setting the agenda for a trial. As Laudan points out, “...they determine, for instance, how a jury is selected, what sorts of verdicts are subject to appeal, who can interrogate whom, what instructions the judge gives to jurors, what standards the judge must use for his various rulings, and sundry related matters. Obviously, such procedures can profoundly influence the outcome of a trial". See id.

${ }^{23}$ See id. at 121. A particular evidentiary item is relevant if it has the property of increasing or decreasing the likelihood that the hypothesis concerned is true. For its part, a particular evidentiary item is reliable if there are grounds for believing that its content (from which we infer other facts) is true. These grounds may be considered as particular conclusions which stand as outcomes of a scrutinizing process that takes into account factors such as distance, amount of time observing the event, visibility conditions, perceptual or cognitive deficiencies or abnormalities, time passed since the event concerned was witnessed, and the like (in the case for instance, of an eye-witness testimony). As the incidence of these factors may differ, reliability assessments constitute an activity that admits of degrees (contrary to relevance assessments), and thus, a particular evidentiary item may be more or less reliable - depending on the strength of its grounds - within a spectrum of values of reliability. The turn now is for redundancy: A particular evidentiary item is redundant if it can reasonably be established that it 
(p2) "Rules of Procedure should be designed to optimize the likelihood that the triers of fact, typically jurors, receive their information in a way that enables them to draw valid inferences from the evidence about the guilt of the accused. That is, procedures should be chosen so as to reduce the likelihood of an invalid verdict." ${ }^{24}$

The notion of validity in (p2) aims to capture something important about the quality of evidence-assessments carried out by the trier of fact both at the local level (when some weight or probative value is assigned to a particular item of evidence), and at the global level (whether or not the holistic probative value of the evidence as a whole satisfies the standard of proof set in place). In this line, either when the trier of fact gives more or less weight or probative value to a particular evidentiary item than it genuinely merits, or when she misconceives the height of the standard of proof by interpreting it lower or higher than it actually is (assuming of course, that the sufficiency threshold is reasonably clear and objective), the verdict is inferentially flawed, and thus, invalid. ${ }^{25}$

Equipped with these general guidelines about truth-promoting profiles, we can move on to Part Two of this essay where we will identify and explore certain truth-thwarting patterns, which will emerge as norms and practices that are contrary to the general guidelines set out before, and hence constitute a systematic violation of the victims' right to truth in the sense previously stipulated.

We will focus on the international criminal law arena, and we will identify as an instance of a truth-thwarting pattern what Combs calls a Pro-Conviction Bias $(\mathrm{PCB})$ - which transgresses the parameters set out by $(\mathrm{pl})$ and (p2) - . This pattern has been arguably implemented progressively at the legislative and jurisprudential level of the ICTY, and perhaps more clearly, at the domain of actual practices at ICTR, the Special Court for Sierra Leone (SCSL), and the Special Panels for East Timor. In particular, the PCB transgresses the parameters set out by (p1) and (p2).

would contribute with no significant impact in a pre-existing evidentiary profile supporting a proposition, in terms of boosting (or decreasing) such support.

24 See id. at 121.

${ }^{25}$ Id. at 13, 195. Nonetheless, it is important to note that the property of being valid or invalid does not necessarily warrant either the truth or the falsity of the conclusion reached by means of the inference(s). The truth values of the proposition that states that John committed the crime concerned, or of the proposition that states the opposite, depend exclusively on an agreement - or on a lack of it - between the propositions' content and reality, thus creating the possibility for valid-false verdicts, and for invalid-true ones to exist. Of course, it is desirable that most of the time the verdicts' compliance with the rules of evidence and procedure could justifiably be considered as a strong indicator of their truth. Nonetheless, deliberative steps have to be taken to get as close as possible to this ideal epistemic scenario which imply the willingness to monitor the system and to put in place the best rules and practices available at a particular time (which may of course prove flawed as the monitoring operations continue as part of an on-going project of legal epistemology). 


\section{The Pro-Conviction Bias}

\section{The International Criminal Tribunal for Yugoslavia (ICTY)}

Scholars and practitioners such as Circuit Judge Peter Murphy, ${ }^{26}$ Eugene $\mathrm{O}^{\prime}$ Sullivan, and Deirdre Montgomery ${ }^{27}$ — all of whom have had extensive defence counselling experience at the ICTY - have recently raised their voices to denounce certain ICTY's practices, in particular those described as truth-thwarting patterns since their recurrence impairs (mostly in detriment of accused parties) the ability to make accurate factual determinations.

\section{A. Lack of Evidentiary Gate-Keeping}

Murphy's analysis highlights a pivotal judicial flaw in the Tribunal's evidence admission practices that may be characterized as the "everything goes bias," according to which judges have declined to exercise the broad discretionary powers conferred to them by the ICTY statute (which at least theoretically, allows them to exclude unreliable evidence), and thus, they have abdicated their general responsibility for the efficient management of the information that they come to learn about the alleged crime(s), in the sense of assuring that this information satisfies a minimum (epistemic) quality threshold at an early stage of the proceedings.

This bias manifests as the constant and systematic indiscriminate admission of whatever the parties regard as evidence without engaging in an (even rough and preliminary) enquiry into the particular evidentiary items' (indicia of) reliability, and into the possibility that the evidence concerned may have been manufactured or subjected to some sort of distortion by the parties (a risk that, as we will see below, increases at the international level as parties may be plausibly said to be motivated by a plethora of incentives that are not present, or not with such intensity, at the domestic level).

One of the main theses advanced by Murphy is that the indiscriminate admission of arguably relevant evidence without having it critically filtered at an early stage (where only the best evidence survives), for one part has the effect of making trials last longer than they need to, and for the other, increases the risk of incorrect adjudication as a frequent outcome of the legal proceedings. ${ }^{28}$

${ }^{26}$ See Peter Murphy, No Free Lunch, No Free Proof. The Indiscriminate Admission of Evidence is a Serious Flaw in International Criminal Courts, 8 Journal of International Criminal Justice 539573, 2010.

${ }^{27}$ See Eugene O'Sullivan et al., The Erosion of the Right to Confrontation Under the Cloak of Fairness at the ICTY, 8 Journal of International Criminal Justice 511-538, 2010.

${ }^{28}$ See Murphy, supra note 26, at 540. 
In this line, Murphy claims that the merely logical relevance of an evidentiary item does not necessarily contribute in a positive way to the flesh and bone judges' enterprise of accurately determining the facts of a case via evidence assessment. Thinking otherwise is, as Murphy identifies, a central feature of Civil Law lawyers' and judges' background, for whom the whole bulk of exclusionary rules of evidence developed by the Common Law constitute an obstacle for truth-seeking objectives (as they understand them).

Murphy's critique to this approach is that the mantra in which Civil Law judges are socialized, which states that they are able to fairly and impartially assign the genuine probative value that a piece of evidence merits - even if that value equals cero - at the end of the trial-drama (just before they are about to determine whether the defendant is guilty or not) without any preliminary and even rudimentary assessment of its quality as a prelude to the decisive evidence-evaluation task, simply does not hold in practice: ${ }^{29}$

Once unreliable and potentially fabricated evidence is admitted it becomes part of the record, increasing the overall volume of putative evidence (and thus increasing too the level of complexity of the evidence-evaluation task as judges become unnecessarily overburdened with more and more information to be assessed); ${ }^{30}$ it is available for parties to be used and recursively referred to throughout the trial (which as the international experience has shown, may last years) as they call witnesses and address arguments to the Court (and thus, the putative evidence undergoes a process of progressive confirmation); ${ }^{31}$ but the most important effect of the admission of this type of "evidence" takes place inside the mind of the judge, who has the amazing challenge of making sense of all the evidence available in a coherent framework, throughout and as the outcome of, a general process of integration of massive amounts of information.

As the evidence gets integrated in a coherent whole by sophisticated cognitive operations (such as the reduction of "cognitive dissonance" "), the particular evidentiary items are intertwined in an argument-narrative structure the elements of which provide complex reciprocate corroboration support to each other. In this line, an evidentiary item that would have deserved a low reliability value (enough to be reasonably discarded from consideration) if taken in isolation before its fusion with the overall evidentiary profile supporting a particular factual proposition, may be boosted at a later time by other

${ }^{29} I d$. at 551.

${ }^{30}$ Id. at 552 .

${ }^{31} I d$.

${ }^{32}$ The theory of Cognitive Dissonance basically states that people experience an unpleasant feeling when they identify that they are holding contradictory cognitions, which motivates them to engage in a process of changing such cognitions, attitudes and behavior in order to dissolve contradictions and restore consonance. For a very preliminary introduction see the entry of Cognitive Dissonance of the Skeptic's Dictionary, http://www.skepdic.com/cognitivedissonance.html. 
evidentiary items that are consistent with its content, and vice versa as well, producing the metastasis effect that Murphy refers to in the sense of burying (or contaminating) genuinely probative evidence in a sort of evidential debris. $^{33}$

Moreover, the content of a particular evidentiary item once it has become an input of the integration process, also performs the role of a sort of building block, an intermediate inferential step that guides the reasoning chain (may be in conjunction with other inferences) to some direction, which may have not been followed had the originally unreliable and potentially fabricated evidentiary item not been there in the first place.

To complicate matters further, for one part this integration process is triggered automatically as the trial develops, and usually takes place behind curtains in the sense of not being consciously monitored by judges; and for the other, this process plausibly suffers the influence of external factors such as the international community's and victims' pressures regarding the expedite completion of trials in a way that satisfies them (by issuing convictions, see below).

So, by adhering to this mantra ICTY's judges are caught in an illusion: They reach the final deliberation stage in a position where, even if we removed the external pressures from the picture, they are more likely not able even to recognize the initially questionable evidence, and much less able to assign the genuine probative value it originally deserved. But once the external pressures component is reintroduced, their declared willingness to dismiss unreliable information from their minds having suffered a constant exposure to it is all the more implausible (and remains at best as a theoretical aspiration) as they have developed a complex set of strategies with the overall purpose of giving the prosecutor's evidence a condescending treatment (which will become clearer when we recount Comb's research in the following section).

\section{B. Lack of Evidentiary Gate-Keeping and Hearsay Evidence}

In line with the general absence of evidentiary gate-keeping by its judges, the ICTY has been accepting hearsay evidence (mostly in a written format) and unauthenticated documents on an ordinary basis. This practice opens the door to the admission of vast (almost unmanageable) quantities of documentary evidence with no comparison to the amount of information normally received at domestic criminal proceedings due to the inherent largescale nature of international crimes (which means that thousands of alleged victims and witnesses are potentially available), and because of the broad and vague statutory phrasing of some of the characteristic elements of these crimes (such as a "widespread policy" or a "systematic attack" that provide the general framework where acts of genocide and crimes against human-

\footnotetext{
${ }^{33}$ See Murphy, supra note 26, at 552, 543.
} 
ity take place), that has the effect of exponentially expanding the universe of arguably relevant information that the parties may produce, including, as Murphy calls it, "the almost limitless galaxies of background and contextual evidence. ${ }^{\prime{ }_{34}}$ But as they systematically send the message that everything goes, judges are all the more likely to be bombarded with putative evidence by the parties, whose only limit is the amount of resources available to them. ${ }^{35}$

In order to give us an idea of the type of unreliable hearsay evidence that is routinely admitted by the ICTY's Trial Chambers, Murphy states that

...It is common to hear a witness, in reply to a question about what happened to his friend in the detention camp, say something like: 'Well, I don't know myself. I never saw my friend again after he was arrested. But another friend told me that he heard from his brother that my friend was regularly beaten and was later shot by the guards.' Or consider the by no means unusual case, in which a trial chamber admits a report written by an officer of a respected NGO, which relies almost entirely on information supplied by $\mathrm{B}, \mathrm{C}$, and $\mathrm{D}$, who in turn relied on informants E, F, and G, who say they had a sight of documents H, I, and $\mathrm{J}$, which were written by $\mathrm{K}, \mathrm{L}$, and $\mathrm{M}$, etc. etc. potentially ad infinitum... ${ }^{36}$

Murphy points to two basic dangers that make of routinely accepting hearsay evidence a risky business: ${ }^{37}$ One of them is the inherent susceptibility of the message conveyed (the alleged fact) of being distorted in proportion to the amount of the message's repetitions that have occurred in the chain of meta-linguistic references that precede it (a phenomenon that is known as multi-level hearsay). The other and more important danger is that the original maker of the statement concerned (that is being recounted in-Court by the hearsay witness or in a document like a Report from an NGO) is not available for cross-examination by the defense.

As O'Sullivan et al comment ${ }^{38}$ cross-examination is the ultimate means of testing the witnesses' credibility; it allows for frailties of testimonies (given by even the most honest witnesses) to come to light; it is one of the ways the accused may follow in order to provide an answer and defence to the charges and allegations against her, or to elicit information regarding the facts at is-

\footnotetext{
${ }^{34}$ As an example of the complexity of issues that are dealt with at the ICTY, Murphy points out that "...the prosecution set out to prove that the motivation for the widespread 'ethnic cleansing' committed by Bosnian Serb and Bosnian Croat perpetrators was the creation of a 'Greater Serbia'or 'Greater Croatia'. To prove these alleged conspiracies, the prosecution has adduced $e x$ tremely detailed evidence about such matters as: the historical rivalry between the three constituent nations of the former Yugoslavia (the Serbs, Croats and Muslims); the historic borders of the constituent Republics of the former Yugoslavia; and political machinations over many years, not only in Bosnia and Herzegovina itself, but also in Belgrade and Zagreb..."; id. at 542.

${ }^{35}$ Id. at 542-543.

36 Id. at 543.

${ }^{37} I d$. at 559-560.

38 See O'Sullivan, supra note 27, at 513.
} 
sue, or regarding an issue favorable to her (in this sense it is a way to raise a reasonable doubt in the prosecutor's case); and it provides the trier of fact with the opportunity to directly observe the witnesses' performance as they take the stand, by which the trier of fact becomes aware not only of the content of the testimony but simultaneously of the non-verbal communication that witnesses engage in while the interrogation takes place.

Moreover, cross-examining a witness is a basic right of the accused and an essential feature of the fair trial doctrine. This right has been well established in the Common Law, in the Sixth Amendment to the US Constitution, in Article 6(3)(d) of the European Convention of Human Rights, and expressly guaranteed by Article 21(4)(e) of the ICTY Statute. ${ }^{39}$ Nonetheless, these legal grounds that are protective of the right to cross-examination do not warrant a general blanket prohibition to admit hearsay evidence at the ICTY. Its admission becomes an issue of balance (or at least it is supposed to be like that). In this line, Rule 89(D) provides that evidence may be excluded if its probative value is substantially outweighed by the need to ensure a fair trial. The problem of course is that ICTY`s judges almost never seem to be sensitive to fair trial concerns that arise out of the general acceptance of hearsay evidence and thus, they do not consider that these concerns ever get to outweigh the relevance of an evidentiary item despite its questionable reliability status. As we have said earlier, Murphy holds that this is due to ICTY's judges' perception of exclusionary rules and practices as useless technicalities, and to their extreme confidence that they will be able to attach the proper probative value to any evidentiary item (provided that it is relevant) at a later point in time (which is why it is seen as having no point to exclude evidence at an early stage on the basis of its low level of reliability. It makes no difference, it is claimed, if this is done at the beginning or by simply dismissing the unreliable evidence from their minds at the final deliberations stage).

\section{The End-of-Orality Policy}

O'Sullivan et al point to the fact that during the period of 1994 to 2000, the ICTY had certain Rules and had produced case-law both of which established a preference for live in-Court testimony, ${ }^{40}$ which for its part tempered to some extent the inherent reliability deficit of the hearsay evidence that was being (and continues to be) routinely accepted by the Tribunal, because at least that way judges would be able to hear and observe directly the witness concerned when she was recounting a statement made by somebody else outside the framework of the legal proceedings, and the defense would have had the chance to cross-examine her (which would be useful to determine her credibility and would ensure minimally the right to a fair trial, even when the

\footnotetext{
39 See Murphy, supra note 26, at 560.

${ }^{40}$ See O'Sullivan, supra note 27, at 516-520.
} 
witness was not the maker of the original statement that was being recounted as proof of its content).

In this line, Article 90(A) established the principle of orality by mandating that "witnesses shall, in principle, be heard by the Chamber;" and for its part, when analyzing the Rules that provided for exceptions to live in-Court testimony, the Appeals Chamber in Kordic found that in each instance of departure from this principle (depositions, video-conference links, expert reports, and affidavits) there were safeguards (which should be warranted) that ensured the reliability of the evidence, one of which amounted to the possibility to crossexamine the witnesses. ${ }^{41}$ O'Sullivan et al highlight that during this period, the ICTY was well aware of the justified criticisms that were usually launched against the Nuremberg and Tokyo Tribunals, which are condensed in the characterization of their practices as "trials by affidavit," and thus wanted to avoid these criticisms by giving preference to oral in-Court debates. ${ }^{42}$

Nonetheless, by 2001 the principle of orality was deleted from Rule 90, and two new provisions were introduced: Rule $89(\mathrm{~F})$ which states that evidence of a witness may be received orally or, where the interests of justice allow, in written form; and Rule 92 bis which provided for the admission of written statements and transcripts prepared for the purposes of the current legal proceedings (or for prior proceedings before the Tribunal, see below the section on judicial notice), and in lieu of oral testimony. ${ }^{43}$ In other words, Rule 92 bis provided for the admission of a particular type of hearsay evidence in the sense that at some point the prosecutor would be recounting uncrossexamined written statements made by somebody else.

In Galic and Milosevic the conditions and circumstances under which it would be appropriate for the Court to admit written statements in lieu of oral testimony were established: The content of the statement concerned could not refer to the "acts and conduct of the accused as charged in the indictment." In other words, the statement's content could not make reference to any critical element of the prosecution's case that was indispensable for a conviction (including aggravating circumstances), which should be supported with evidence that leaves no room for reasonable doubt: the statement - which if admitted would substitute the maker of the statement's appearance in Court - had to be prepared for the purposes of legal proceedings; because of the recognized risk that the document containing the statement may have been fabricated and/or that the information in it could have been favorably skewed by lawyers who may have carefully devised it, the Court had to approach the document concerned with caution; and if the Court found that there was a substantial degree of proximity between the accused and the person engaging in the acts and conduct described by the statement, and the evidence was

\footnotetext{
${ }^{41} I d$.

${ }^{42} I d$.

${ }^{43} I d$.
} 
pivotal to the prosecution's case, it could reject the evidence on the basis of impeding a fair trial. ${ }^{44}$

For its part, and taking distance from the above principles, the Appeals Chamber established in Milosevic that a witness written statement or a summary of it signed by the witness could be admitted as evidence if: (a) the witness is present in Court; (b) she is available for cross-examination and any questioning by the judges; and (c) she attests that the statement or summary accurately reflects her declaration and what she would say if examined. ${ }^{45}$

The core problem with this decision is that because the Appeals Chamber considered that in this type of cases the evidence concerned was governed by Rule $89(\mathrm{~F})$ previously referred to, the admissibility restrictions of Rule 92 bis would not apply, and thus the statement or summary could refer to the acts and conduct of the accused as charged in the indictment, and the Court could approach it with plain confidence (as opposed to approach it with caution) or at least with no explicit warning, despite the fact that - as highlighted by judge Hunt in his dissenting opinion $-{ }^{46}$ this evidence shares with the special kind of hearsay regulated by Rule 92 bis the common feature of having been prepared (with the assistance of lawyers) for the purposes of the legal proceedings, and thus, the risks of fabrication and misrepresentation are also present.

One might point to cross-examination as a still available option in this scenario to ensure the reliability of the evidence. The point is that crossexamination (if at all exercised) would stand on an uneven ground for the carefully devised and lawyer-assisted written version of the witness' testimony would substitute - against the reasoning laid down in Kvocka ${ }^{47}$ the oral examination in chief that should be conducted by the prosecutor, and would be assumed by the Court as the point of departure for the cross-examination to proceed, which in turn means loosing the opportunity to directly observe and hear how the testimony-giving dynamics develops naturally without any assistance, and simultaneously carries the distortion of the nature of oral debates.

\section{Fudicial Notice of Adjudicated Facts}

Another practice that undermines the accused' right to hear and efficiently confront the evidence against him and that increases the risk of a final decision being made on the basis of potentially unreliable evidence is the judicial notice of adjudicated facts:

The doctrine of judicial notice considers common-knowledge facts as the only instance in which the general principle that all the relevant facts to a

\footnotetext{
${ }^{44} I d$.

${ }^{45} I d$.

${ }^{46} I d$.

${ }^{47} I d$.
} 
dispute have to be supported by evidence, could reasonably not apply. ${ }^{48}$ Nonetheless, the Statute of the ICTY has broadened this scope by incorporating a provision - Article $94(\mathrm{~B})$ - to the effect that the Trial Chamber "may decide to take judicial notice of adjudicated facts or documentary evidence from other proceedings of the Tribunal relating to matters at issue in the current proceedings." ${ }^{49}$

In addition to the expansion of the universe of noticeable facts by the Chamber provided by Article 94(B), the ICTY has gone as far as to establish the possibility that the Trial Chamber may take judicial notice of facts that are susceptible to reasonable dispute in the current proceedings, thus departing from its own previous jurisprudence in Simic and Kvocka which reflected the common practice (before Milosevic) of not taking judicial notice over the objection of the accused, where there was not an agreement between the parties as to the facts proposed by the prosecutor to be noticed, and where the accused demonstrated that these facts were matters that needed independent determination. ${ }^{50}$

Lots of problems arise with the possibility previously referred to, but I will focus on one of them: Taking judicial notice of facts that are susceptible of reasonable dispute in the current proceedings faces the general fair trialrelated objection that the parties (for instance, the accused) of the previous trial lack the appropriate incentive structure in order to litigate the alleged fact concerned in a manner that would be favorable to the defence strategy of the accused in the current proceedings. May be the accused of the previous trial was totally indifferent to the fact that becomes relevant in the current proceedings and thus, maybe she did not argue anything at all or argued insufficiently from the perspective of the interests of the current defendant.

In order to temper to some extent this general fair-trial concern regarding the practice of noticing adjudicated facts capable of reasonable dispute in the current proceedings, the ICTY allowed the accused of the current trial to refute the noticed fact concerned, thus creating an unnatural dynamics for debates and disputation that we will proceed to analyze:

According to the ICTY's Case-Law, the adjudicated fact noticed by the Trial Chamber has the status of a presumption in the sense of shifting the burden of proof to the accused, which in turn has the right to challenge the noticed fact by adducing evidence to that effect. The problem of course is one of defining the success criteria to be satisfied by the accused's refuting evidence in order to defeat the presumption; or in other words the issue is: what is the weight of the presumption that is established by noticing an adjudicated fact?

It seems that an agreement upon this question has not been reached; sometimes the presumption is regarded as a "well-founded" one (due to the

\footnotetext{
${ }^{48}$ O'Sullivan, supra note 27 , at 520-526.

${ }^{49} I d$.

${ }^{50} I d$.
} 
previous judicial scrutiny that the likely fact has been subjected to), which is arguably stronger than a plain an ordinary presumption; and sometimes the departure weight of the presumption seems even stronger.

In this line, in Karemera the Appeals Chamber considered that the burden placed on the shoulders of the accused was analogous to the onus that comes with the attempt to establish an affirmative defence (like self-defence), which consists usually of proving the elements of the defence concerned to the standard of the Preponderance of the Evidence (PoE).

If in deed the PoE standard applies, this is troublesome for the principle of the Presumption of Innocence (PoI), for the more general precept of granting the Benefit of the Doubt (BoD) to the accused, and for the error-distribution figure that the standard BARD is supposed to both imply and warrant (the Blackstone ratio that "it is better to acquit 10 guilty defendants than to convict one innocent"). By imposing a PoE standard to the accused in order to defeat the presumption created by certain previously adjudicated fact being noticed in the current proceedings, we are setting in place great obstacles to the accused which amount to imposing a burden of generating more than a reasonable doubt in order to stop the prosecution's case from being successful; and ultimately we are saying that it is not the case that convicting the innocent is as serious and costly as the Blackstone ratio conveys.

But more confusion surrounding this critical issue is generated due to the fact that while making the burden that is shifted to the accused when an adjudicated fact has been noticed analogous to that of a defence, the Appeals Chamber used the example of an alibi. As pointed by O'Sullivan et al, the problem is that the jurisprudence of the same Appeals Chamber has established that it is a mistake to characterize an alibi as a defence. In this sense, once the accused invokes an alibi there is no onus for him to establish it (as opposed to when a defence is invoked). Of course some evidence has to be produced to back up the alibi allegation, but it does not have to satisfy standards of proof like PoE or BARD. This situation requires the prosecutor to eliminate the reasonable possibility that the alibi is true by challenging the evidence adduced by the accused on this issue. So, it is not clear if the burden that the accused has to discharge when facing a presumption created by a noticed adjudicated fact is the standard PoE or the lower one that consists of only "producing" evidence in order to make the allegation that the noticed fact is not true a "reasonable" one.

\section{E. Admission of Co-Accused Statements in Multi-Defendant Trials}

The final practice that along with the previously described jointly provide the general picture of the ICTY's truth-thwarting patterns takes place in the contexts of multi-defendant trials. This practice consists of admitting a co-accused statement produced before, or an interview conducted by, the prosecutor, during the phase where the current co-accused (who makes the 
statement or is interviewed) was only a suspect. These statements and/or interviews may be admitted even when they refer to the acts, conduct and mental states of the co-accused..$^{51}$

The main problems with this practice are that judges cannot directly observe and hear the testimony of the co-accused in order to determine her credibility and that the co-accused (which is affected by the content of the statement or interview) may not be able to exercise his right to cross-examination due to the fundamental right to remain silent - established in Rule 21(4) (g) - that may be invoked by any co-accused.

Furthermore, there are reasons to remain skeptical about the reliability of this type of evidence given that it is produced in a context where the suspect (that later becomes the co-accused) has every opportunity - and plausibly takes it frequently - to minimize her role and to highlight or even exaggerate the role of others regarding the crimes investigated for which she and her coaccused are later charged with. It is a context where the prosecutor may also take advantage of her position in order to exert some sort of pressure to, and bargain with, the suspect, in order to procure "solid cases" to be tried before the Trial Chamber.

These reasons to remain skeptical have been acknowledged by the ICTY in Blagojevic. ${ }^{52}$ Nonetheless, in Prlic and Popovic they were contested by the Appeals Chamber which stated that the suspect is not only and not necessarily prone to mislead or lie during the investigation phase; this stage, it is claimed, also poses the opportunity for her to tell the truth. Regarding the issue of cross-examination the Chamber reasoned that even if it the co-accused were treated as if they were being tried separately — which would give each of them the opportunity to call the current co-accused as witnesses - once called they could invoke their right regarding self-incrimination - Rule 90(E) - and thus, it would be useless for cross-examination purposes..$^{53}$

Against this reasoning, O'Sullivan et al argue that despite the possibility that the co-accused may invoke her right not to testify regarding matters that might incriminate her, there is still ample room for questioning via crossexamination regarding matters affecting her credibility, regarding evidence relevant to the case of the cross-examining party, and regarding matters on which the Chamber permitted inquiry. But if the ICTY insists in the practice of not treating the co-accused separately, the fact that the right to hear and efficiently confront the evidence against her and the right to remain silent collide producing irreconcilable tensions, should be taken as an absolute reason not to admit statements or interviews from the co-accused in multi-defendant

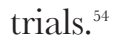

\footnotetext{
${ }^{51}$ O'Sullivan, supra note 27, at 526-528.

${ }^{52} I d$.

${ }^{53} I d$.

${ }^{54} I d$.
} 


\section{F. ICTY's Plausible Motivations for Implementing Truth-Thwarting Patterns}

We move now to analyze the issue of the motivations that the ICTY might plausibly have for its lack of evidentiary gate-keeping and for the progressive implementation of a policy in order to maintain orality to a minimum (hence privileging evidence in a written form), which as a consequence undermines the nature of debates, the accused' right to hear and efficiently confront her accuser and the evidence against her, and ultimately undermines the Tribunal's overall epistemic potential by increasing the risk of final decisions being based upon unreliable and un-cross-examined (or deficiently cross-examined) testimonies and unauthenticated (potentially fabricated) documents, despite the judges' belief and extreme confidence that they have attached the probative weight that this evidence genuinely merits and that the determination that the standard BARD has been properly made.

In Murphy's analysis the general lack of evidentiary gate-keeping at the ICTY is the result of the influence of Civil Law lawyers - like the President of the Tribunal, the Judge Antonio Cassese - and the implementation of a Free Proof system thereof. ${ }^{55}$

The basic tenet of this system is that all relevant evidence should be admitted regardless of its degree of reliability, which will be adequately — almost infallibly - established by professional judges (who also play the role of factfinders) in their final deliberation. The judges' professional status is thought to be a sufficient guarantee in itself that they do not need any guidance as to how to conduct probative-value-attributions and that they are perfectly capable of critically filtering only the sufficiently reliable evidence at the final deliberation stage despite the fact that the unreliable evidence - that is supposedly erased from their minds once its deficient quality has been detected - had been part of the record and had been available for the parties to be continuously referred to throughout the whole trial. ${ }^{56}$

The Free-Proof system - a term which is considered by Murphy to be a euphemism for the systematic failure to inquire into the evidentiary items' indicia of reliability and into the possibility that they may have been fabricated - is plausibly based upon an aversive attitude from Civil Law lawyers toward the whole issue of applying exclusionary rules of evidence. For its part, according to Murphy, this aversive attitude makes the faulty assumptions that having exclusionary rules is a property that belongs exclusively to jury-systems (which is not the case), and that the bulk of these rules are obstacles for truth to emerge as a frequent outcome of the proceedings.

To contest the second assumption Murphy holds that rather than hindering triers of fact (whether judges or members of the jury) in their efforts to determine the facts of a case, some exclusionary rules actually facilitate

\footnotetext{
${ }^{55}$ See Murphy, supra note 26, at 555-556.

${ }^{56}$ Id. at 545-551.
} 
truth-seeking objectives by setting the best environment for correct adjudication to emerge frequently, because they allow for only the best available evidence to be considered, and because they represent efficient measures to shield the proceedings from the risk that parties may abuse their right to adduce evidence by bombarding the Court with potentially inaccurate information (nonetheless favorable to their case).

This risk of abuses by the parties pursuant to their own goals is inherent to the more general category - than jury trials - of adversarial systems where the proceedings are designed to be generally benefited in terms of evidence gathering, evidence presentation and argument devising, from the reasonable assumption that the parties have the intention to win their case. Nonetheless, the adversarial system also recognizes - and takes measures about it - that the parties' objective of winning and the arguable legal proceedings' objective to find out the truth may diverge, hence generating the risk that the information that the triers of fact receive may not be sufficiently reliable due to this conflict-of-interests-scenario.

As Murphy explains, there are reasons to be even more careful at the international level regarding the risk previously referred to due to the fact that in most cases where international criminal justice is activated the conflicts that provide the context for massive and widely spread violence have been nurtured through many years (may be decades or even centuries), they imply a complex set of ideological convictions underlying them, and they are deeply rooted in the collectivity's memory. In this sense, the different groups' versions of the facts are non-negotiable and sometimes even become part of their members' identity. It is naive to some extent to think that the conflict ends when the proceedings start; the hostilities may have stopped (hopefully for a long period), but the ideological battle may take over the Court. This battle of heart-convictions is plausibly not bound (or not sufficiently bound) to ethical self-constraints that would guarantee to some extent that only reliable evidence will be voluntarily submitted by the parties. But as the Tribunal sends the message that all "evidence" will be preliminary admitted (with the hope of dismissing the unreliable items at the final deliberation stage), the temptation to fabricate or distort evidence becomes all the more attractive (and even reasonable as means available for the parties), and as we have said before, the only limitations to this practice would stem from the amount of resources available to the parties. ${ }^{57}$

Now, turning to the motivations that the ICTY may have had to implement a progressive policy against orality - which is translated into a real affront to the accused' right to confront the evidence against her- O'Sullivan et al point to the Completion Strategy endorsed by the ICTY as a result of UN Security Council's resolutions. This Strategy mandated the ICTY (and the ICTR too) to take all possible measures to complete all the investigations by the end of 2004, to complete all trial activities in the first instance by the

${ }^{57} I d$. 
end of 2008, and to complete all the Tribunal's work by the end of 2010. This Strategy also requested from the Prosecutor and from the President of the Tribunal a report specifying their plan on how to implement the guidelines of the Strategy. ${ }^{58}$

\section{G. Sumary}

To recap, the practices described in this section constitute what we have called truth-thwarting patterns in that their constant occurrence impairs the ICTY's ability to make accurate factual determinations. As we have seen, the Tribunal's epistemic potential is undermined mainly in detriment of the accused.

More specifically the general lack of evidentiary gate-keeping (that we have also referred to as the "everything goes bias") violates (p1) in that it allows for unreliable evidence to get passed the admissibility bar (which is reduced to the determination that the evidentiary items concerned are relevant or not) and become an input of the information stream within the proceedings. But this practice also violates (p2) in that it constitutes a procedure that is more likely to generate more cognitive overload for judges and to create confusion regarding the probative value that an evidentiary item genuinely merits, which increases the risk of making erroneous assessments of evidence both at the local and the global levels.

\section{The International Criminal Tribunal for Rwanda (ICTR), Special Court} for Sierra Leona (SCSL), and the Special Panels for East Timor (Nancy Comb's Findings)

In her recent book "Fact-Finding without Facts; The Uncertain Evidentiary Foundations of International Criminal Convictions, ${ }^{59}$ Professor Nancy Combs reports the results of an illuminating research based on a thorough review of thousands of pages of transcripts from which she convincingly concludes that international criminal tribunals and courts such as the ICTR, the SCSL, and the Special Panels in East Timor (hereafter, the Special Panels) systematically face what she has called "severe fact-finding impediments" due mainly to the highly questionable eye-witness testimony on which their factual determinations are primarily based.

Comb's cconclusions raise serious doubts about the accuracy of these tribunals' findings regarding who did what to whom. The author even suggests that the pervasiveness of this major fact-finding flaw transforms international criminal proceedings to mere show trials. ${ }^{60}$

\footnotetext{
${ }^{58}$ See O'Sullivan, supra note 27, at 535-538.

59 See Combs, supra note 1.

${ }^{60}$ Combs states that: "By using the Western trial form, international criminal proceedings
} 


\section{A. The Prevalence of Eye-Witness Testimony at these Tribunals}

In order to explain eye-witness testimony as prevalent, Combs points out that contrary to the Nuremberg trials - where the high-level Nazi officials that were prosecuted were convicted on the strength of their own documents - today's architects of wide-spread violence are not prone to keep meticulous records of their activities nor to leave documentary traces behind them; and even when they do leave some written records their availability for prosecutors is compromised due to the fact that international criminal justice still depends to a large extent on States' voluntary cooperation, which may not be politically convenient for particular States at a given time.

In addition to this general point, Combs urges us to keep in mind that the communities and societies living in what has become the territorial jurisdiction of the ICTR, the SCSL, and the Special Panels (and similarly in the current situations and cases at the ICG), view and understand their social world in very different terms than those associated to the western conceptual schemata ${ }^{61}$ In this line, basic expectations and implicit assumptions made by western-like criminal law institutions are not fulfilled, one of which is that the community concerned has implemented a well-functioning record-keeping habit as part of the ordinary interactions between its members and between them and the institutions set at place, which for its part would perform the role of an important documentary-evidence-supply for prosecutors, defence counsel, and for the tribunals' officials in general. When we take into account that these communities are primarily oral cultures and underdeveloped countries which live in conditions of massively spread poverty and even misery, these assumptions start to collapse.

For its part, forensic evidence is usually not obtained nor presented at international trials. With the exception of the Special Panels where the violence was short lived and the UN forces entered and controlled the territory immediately after the violence ended, exhumations and autopsies were not able to be performed in the cases of Rwanda and Sierra Leone because the magnitude of the atrocities as to the former, and the long length of the war in

cloak themselves in the form's garb of fact-finding competence, but it is only a cloak, for many of the key expectations and assumptions that underlie the Western trial form do not exist in the international context. International tribunals hear evidence and make determinations about what a particular defendant did or did not do at a particular place and time on the basis of that evidence, as fact-finders in other Western trials do; but, given the quantity and nature of much of the testimony that the tribunals receive and their limited capacity to verify facts, these determinations in many cases constitute little more than guesses." See id. at 179; "...proceedings at the ICTR, SCSL, and the Special Panels are conducted in a way that creates the illusion that they are routinely capable of reaching reliable factual conclusions on the basis of evidence presented to them, when in fact, they are not. The Trial Chambers are adrift in a way that calls into question the very foundation of the international criminal justice project." See id. at 186.

${ }^{61}$ Combs, supra note 1 , at 81. 
the latter case, without the international community stepping in and with the absence of local political will to clarify the matter, made forensic investigations impractical..$^{62}$ As the author explains, the only forensic evidence that the ICTR has received has been introduced to prove the very general proposition that there occurred a genocide (that is, that a large-scale massacre took place, and that the vast majority of victims were Tutsi); and even in the case of the Special Panels, the forensic evidence introduced, though it was apt to determine with some certainty the existence and nature of the crimes referred to in the respective indictments, it was not prone to help the fact-finders in their determination of the role (if any) of the defendants in the alleged crime $(\mathrm{s}){ }^{63}$

\section{B. General and Contextual Caution Regarding Eye-Witness Testimony}

Before discussing the particular deficiencies of eye-witness testimony at the ICTR, the SCSL, and the Special Panels, Combs refers to the general inherent inaccuracy (which of course can manifest itself in various degrees) of this kind of evidence even in the best of circumstances:

To start with, the author recalls that according to recent studies, with the advent of DNA testing it has been shown that in the US for instance, nearly 80 percent of the wrongful convictions involved erroneous eye-witness identification. ${ }^{64}$

But certain features that are also at work in international criminal trials increase the likelihood of inaccurate testimony, such as the well established fact that memory of faces fades away over time; ${ }^{65}$ the fact that individuals who witness (or are victims of) violent events are more likely to misperceive than individuals who witness non-violent events because the ability to perceive declines when an individual is experiencing stress ${ }^{: 66}$ and the fact that the introduction of post-event information may produce distortion of memories ${ }^{67}$

Regarding the first feature, we must take into account that it is not the rule that international trials start just after the violence ended. Several years usually go by before an actual international tribunal is set at place. Furthermore, trials individually tend to last for years too, and the overall tribunal's activities may still continue to this day (like in the case of the ICTR). So, we end up with witnesses testifying in relation to events that took place approximately 15 years ago.

Regarding the second feature, the author observes that international witnesses - mostly surviving victims or intended victims - are asked to give tes-

\footnotetext{
${ }^{62} I d$.

${ }^{63} I d$.

${ }^{64} I d$.

${ }^{65} I d$.

${ }^{66} I d$.

${ }^{67} I d$.
} 
timony pertaining to events that are the most violent imaginable, and thus, the most stressing too. In this sense, Combs states that "it is frightening to consider the inaccuracies that are apt to be contained in international tribunal testimony, during which witnesses describe amputations, decapitations, gang-rapes, and large-scale massacres..." ${ }^{96}$

Finally regarding the third inaccuracy increasing feature, Combs points to research that has shown that the memory of an event may be substantially altered by the information that the witness concerned later learns about that event. One way in which new information may be introduced as part of the memory is the following: Studies show that new information (with the consequent risk of distortion by its incorporation to the memory) may be introduced - deliberately but mostly without that intention - by the postcrime police questioning itself, deeming this eliciting activity as potentially distortive of the memory that is being recollected. In this line, given that they are frequently interviewed numerous times before the international trial commences, it is likely that international witnesses' memories are being distorted to a certain extent in direct proportion to the number of pre-trial interviews, by the same efforts of the prosecutor's personnel to elicit from them the information needed to have solid basis for the indictment.

Another way in which new information may be incorporated in (and contribute to the modification of) the witnesses' original memories is due to the widely spread post-crime discussion that is likely to occur among the victims and intended victims of the atrocities that took place. In this line, contrary to what is usually the case in ordinary local crimes, where the victim of an assault for instance does not receive information and particular details about the crime concerned by her family or by any other source (in this sense, the assault constitutes an event that happened exclusively to her), the victims that survived a genocide or crimes against humanity have themselves to talk to and to constantly recount the events from their perspectives as victims.

Within this complex communicative process, the witnesses' memories are continuously subject to revision, during which different elements not "known" before are integrated in the broad mental narrative of the event that each victim is prone to create in order to make sense of the violent episode they experienced. So, in a sort of cascade effect the community collectively and progressively re-writes the story of what happened out of various potentially distorted versions of the facts produced by its members, of whom it may be plausibly said that they witnessed the events (if they in fact did witness them at all, see below) in a scary, vulnerable, and stressing mode (where survival was the primordial goal), surrounded by chaos all over the place.

Moreover, the distortive potential of collectively re-writing the story of the crimes increases when we take into account that the Rwandan, Sierra Leonean, and East Timorese witnesses - who live in an environment of an

${ }^{68} I d$. 
oral tradition - do not generally distinguish (or do not care) between having themselves seen the events and having been told aspects about them by someone else who is recounting those events. They have a tendency to endorse the recounted events as if they had been personally there to observe what happened. And even when they admit in court that they did not witnessed personally the event concerned - which they are supposedly recounting - they don't seem to understand why this worries the western enquirer so much. The event in question is part of the community's collective knowledge regardless of how their individual members came acquainted with it; either by personal direct observation or by indirect vicarious knowledge, it makes no difference to them.

\section{G. The Nature of Testimonial Deficiencies}

According to Combs, when questioned by the prosecutor, judges, or by the defence, international witnesses behave as follows:

a) They try to evade the question, which leads to no answer at all;

b) When they do answer, sometimes they do so unresponsively (either because the answer is incomprehensible to the court's personnel or because it amounts to information that is not pertinent);

c) Even when relevant, the answer is too vague;

d) Sometimes the answer is subsequently proven inaccurate;

e) And most worryingly, sometimes the answers are inconsistent either with prior pre-trial statements of the witness, or with other witnesses' testimony.

\section{Unconveyed Information}

The information unconveyed amounts to the following:

a) Basic personal facts (such as the age of the witness, the year that she was born, how long she had been married, how long he had been a mechanic);

b) Contextual information (e.g., the number of Rwandan sectours; how the Sierra Leonean government gained power; the identity of the appointed East Timorese village head; the general context of the conflict which gave rise to genocides or crimes against humanity);

c) The dates on which the crimes allegedly witnessed occurred (sometimes the witnesses are able to say that the events took place during the "dry season" or the "rainy season," or even during a particular month, but that is as good as it gets. Sometimes they cannot tell even the year during which the crime allegedly occurred. On some occasions witnesses 
are mistaken as to the dates they give despite of their conviction. They come to learn about their mistakes through corrections made by judges, prosecutors or defence council).

d) Relevant distances (witnesses often claim ignorance of Western units of measurement; when asked to estimate, for instance, how long it takes from one point to another either by foot or vehicle, they are often unable to answer. Sometimes witnesses give answers such as "a bit far," often seem to guess, like when Sierra Leonean witness TF1-024 was first asked if a particular kitchen was half the size of the courtroom, he answered that it was; but later when asked if the same kitchen was the size of a quarter of the courtroom, he also said yes);

e) Numerical estimates (witnesses are often unable to answer questions such as how many attackers were present at a massacre, or how many civilians were illegally detained. They often give answers like "they were as numerous as ants," or "there were many");

f) Specific details (such as vehicle models, or the type of gun used by attackers);

g) The identification of sites using maps, photographs, sketches or other two-dimensional representations (e.g., when provided a sketch of the crime scene, Special Panels defendant Hilario da Silva responded "if we go to Lautem, I'll show you, but I don't understand this paper." Another Rwandan witness refused to even look at a photograph saying "please, don't drag me on photographs, I never studied photography or sketches, photos are for intellectuals").

\section{E. Problems Arising from Unconveyed Information}

The unconveyed information just recounted gives rise to the following problems: The absence or inaccuracy of this information makes it hard for the tribunal concerned to assess the credibility of the witnesses. This is relevant information that the tribunal should have access to in order to accurately determine the probative value of individual evidentiary items.

For its part, this environment of deficient, incomplete or even absent information is troublesome for the defendant in that she is not able to effectively exercise her right to defend herself by way of challenging the prosecutor's evidence or by presenting an alibi. As Combs puts it

When a witness cannot name the make of the defendant's car, then the witness's account cannot be undermined by evidence showing that the defendant drove a car of a different make. When a witness is unable to say for how long the rebels occupied his village, then the witness's testimony cannot be inconsistent with that of another witness who might estimate a shorter or longer occupation. And when a witness professes not to understand maps or photographs, the witness renders the defence unable to prove that she was never even at the 
scene of the crime. In other words, all manner of innocent inaccuracies as well as deliberate lies can be concealed through a witness plausible claim that he is unable to answer a question. ${ }^{69}$

In this line, the possibility that the defendant may point to a reasonable doubt in the prosecutor's case as a holistic effect of diversified but jointly considered assertions in the direction that key witnesses are unreliable in various respects (due to factors such as that they were placed at a very far away position from the events they are recounting, that the visibility conditions were inadequate, that their testimony is plagued with inconsistencies, and the like) is undermined.

Finally, the testimonial deficiencies outlined previously stand in the way of the tribunal's broader and main task of determining the facts of the case. In this sense, judges are left with weak basis to accurately determine the nature of the crime(s), but more importantly, the nature of the defendant's involvement (if any) in the alleged crime(s) (recall that judges don't usually have any other means to corroborate testimonies or even to decide between competing accounts given by different witnesses).

Nonetheless, as we will see later, despite this weak basis to accurately determine the facts, the Trial Chambers of these international tribunals issue convictions in the vast majority of cases. But "how is this possible?" we might ask given the supposed strong built-in safeguard of a very exacting standard of proof such as beyond all reasonable doubt (BARD). We will get back to that in a moment; in the meantime let us analyze what could plausibly be causing the vast quantities of testimonial deficiencies previously outlined discarding for now an intentional or deliberate component on behalf of the witnesses (that is, giving them the benefit of the doubt).

\section{F. Innocent-Causes of Testimonial Deficiencies}

Following Combs, we can explain away these testimonial deficiencies by making them attributable to very convincing innocent-causes (which the author suggests to be taken seriously by empirical research specifically related to the witness population at these international tribunals), such as the following:

a) Vague, inaccurate, and inconsistent testimony could be the result of factors such as the general low levels of literacy and education of international witnesses in African conflicts: In this line, Sierra Leone has perhaps the lowest literacy rate in the world, at 35 percent. East Timor is not much better, at 43 percent, and in Rwanda, less than two thirds of the population can read and write. ${ }^{70}$

\footnotetext{
${ }^{69}$ Combs, supra note 1 , at 36 .

${ }^{70}$ Id. at 63-66.
} 
b) In addition to the lack of formal education, these international witnesses are likely to also lack the kinds of life experiences for which that sort of "school" knowledge would be useful."1

c) Lack of basic witness skills, such as the skill of conveying the firsthand experiences they witnessed in a reasonably articulated, clear, coherent, and detailed way, which for its part is indispensable for the fact-finder's efforts of evaluating the charges against the defendant, and for assessing the credibility of these witnesses. Nonetheless, due to the general low levels of literacy and education and to the lack of life experiences for which the "academic" knowledge would be useful, the possession of this skill is inherently doubtful. Another crucial skill that is assumed by the Western criminal proceedings is that witnesses will be able to understand and maintain a rational discussion - in a question and answer format - pertaining to a particular legally relevant issue. In this line, it is assumed for instance, that witnesses will be able to grasp the sometimes sophisticated questions that they are asked, such as compound or multipart questions. Witnesses have shown not to understand interrogation of this type, and thus, judges have had to become very active (and even overprotective) in the hearings instructing the lawyers to separate the respective questions. Some other times, these international witnesses do not explicitly state that they do not understand the question, but this becomes clear when the answer given is not responsive. ${ }^{72}$

d) Lack of familiarity with the Western criminal justice system: One of the aspects that is frequently misunderstood or not understood at all by international witnesses is that of its adversarial nature. In this sense, they often feel aggrieved and insulted when their testimony is challenged during cross-examination, which may lead to evasion and reluctance to answer, or to inaccurate, fast, and lacking in details responses just to prevent the questioning from continuing. Also international witnesses do not see to fully understand the different roles, goals and burdens of the main contenders of the Western-like criminal proceedings: The Prosecutor and the defendant. ${ }^{73}$

e) We also have cultural divergences to consider which certainly influence the methods by means of which people communicate and the subjects considered appropriate to discuss about: For instance, in many cultures, making eye-contact with another is considered a sign of disrespect, so immigrants from those cultures will avert their eyes while testifying, which for its part will typically be considered by Western fact-finders as a sign of being deceptive or shifty, because they depart from the assumption that making eye-contact usually indicates forthrightness and trustworthiness. Similarly, the demeanour shown by criminal defendants

\footnotetext{
1 Id. at 66.

${ }^{72}$ Id. at $38-43$.

${ }^{73} \mathrm{Id}$.
} 
from certain cultures may be also misinterpreted as a lack of remorse when in fact it is only the reflection of adhering to a cultural norm that values stoicism and disdains public demonstrations of emotion. Moreover, while the inability or unwillingness to answer questions that imply the use of Western units of space and time is partially explained by the low levels of literacy and education, this phenomenon is complementary explained by the cultural fact that for instance, the Temme people (the largest tribe in Sierra Leone) do not view space as either arithmetically measured or geometrically analysed, as the anthropologist Littlejohn has determined. In this sense, the size of a farm for example is arrived at by estimating the bags of rice it ought to produce, and similarly, sometimes precise units of space measurement are established ad hoc for the context at hand, such as a stick of the desired size, which may stand as a model to be used in the construction of a house. For its part, international witnesses usually do not seem to understand the importance of providing sufficiently accurate and detailed time estimations that the Western court officials press them to; they tend to use time units in a more flexible and fuzzy way according to the nature of the events being recounted, to the role that the witness performed in that event, and the like. ${ }^{74}$

f) Interpretation errors: Besides the natural risk of committing translation and interpretation mistakes in general, the international tribunals and courts that Combs analyzed in her study face particular and serious problems. The Special Panels for instance, were severely understaffed in interpreters, which for its part caused hearings to be postponed, judgments to be issued in only one of the official languages (that sometimes couldn't even be read by judges of the same Panel), and the rights of the defendants to be constantly violated in that defendants frequently were not able to communicate with their lawyers during the trials, and in that defendants could not follow the proceedings because overworked interpreters systematically failed to translate exchanges between judges and counsel. In addition, questioning frequently proceeded through multiple translations because the interpreters sometimes lacked the skill to translate directly from the witnesses' language to one of the court's official languages. Some other times there were no official interpreters available to translate a particular tribal language and so the Panels had to just look around and see who they could find for the task. ${ }^{75}$ Besides all this, the Special Panels faced deeper problems that impaired their translation activities, such as the fact that East Timorese people had never experienced a functional criminal justice system at least throughout the Indonesian occupation period. So, even if the words to convey a particular concept existed, there was still an understanding gap that should

\footnotetext{
${ }^{74}$ Combs, supra note 1, at 79-100.

75 Id. at 66-79.
} 
have been filled with personal or vicarious experience and learning. ${ }^{76}$ For its part, the SCSL sometimes had to abandon verbatim translations in favour of the less accurate tools of summaries of testimonies. Some occasions the SCSL suffered from interpreters' embarrassment to translate obscenities such as in the RUF trial in which an interpreter translated a witness as stating that a rebel had said to a girl "let me have sex with you." A linguist in the translation booth immediately shouted "no" and insisted that the translator corrected his translation to reflect exactly what the witnessed had said, which was that the rebel uttered "I want to fuck you." ${ }^{\prime 77}$

g) Do Investigators' errors explain witnesses' inconsistencies? International witnesses of these tribunals are particularly keen to blame the investigators when their testimony fails to match their pre-trial statement. The most frequent allegation is that investigators omitted information; others claim that the investigators failed to ask the questions currently being answered in court which is why the pre-trial statement lacks this information; and some other times, the witnesses even accuse investigators of inserting fabricated accounts. It is unlikely though that the investigators err as often as witnesses claim they do, nonetheless it is certain that errors do occur and that investigators' work is uneven, and sometimes even incompetent. In some occasions, investigators seemed not to be willing to deep further into a line of inquiry which was simply out of their specified scope. Ideally, if a witness does mention another offender or points to another crime that is outside of the investigator's original scope for inquiry, the investigator would delve further into that matter or at least would send another team to follow up with the witness concerned, but often this does not happen. ${ }^{78}$ On the top of this, it is common that people working as investigators lack an adequate understanding of the general contour of the conflict they are investigating, and of the habits and culture of the people they interview. ${ }^{79}$

\section{G. Non-Innocent Causes of Testimonial Deficiencies (Systematic Perjury)}

In addition to the above innocent-causes, the problematic testimony (particularly in relation to inconsistencies) that the ICTR, the SCSL, and the Special Panels constantly receive and work with may also be explained by alternative frameworks which portray it under the less favourable lights of non-innocent causes, that basically amount to the following possibility: The witnesses are constantly committing perjury, which if true makes of this phe-

\footnotetext{
${ }^{76} I d$.

77 Id.

${ }^{78}$ Id. at $122-129$.

${ }^{79} \mathrm{Id}$.
} 
nomenon a systemic problem to be dealt with. Some of perjury incentives are the following:

a) A cultural component: Scholars have produced evidence in support of the plausible claim that generally in Rwandan and Sierra Leonean societies lying, secrecy, and deception are not as socially condemned as (it is maintained that) it is in Western nations. A general lack of accuracy is accepted, presupposed and encouraged when establishing communication with a fellow member of the community, which even becomes a deeply rooted survival strategy (going back to pre-colonial times) when the communicative episode encompasses a foreigner or an authority as interlocutors. In paraphrasing Overdulve, Combs states that "although one can speak of 'hypocrisy' or 'deceit' in English, there are no equivalent Kinyarwandan words because the Kinyarwandan concepts have positive connotations. Concepts such as hypocrisy are positive values in Rwanda because they are necessary to survive, and a person using them shows his wisdom, prudence, and ability to support himself in that society." ${ }^{\circ 0}$

b) Financial incentives: The per capita income in Rwanda is about 250 dollars per year, which is not as different to the ordinary Sierra Linnean's whose average income is one dollar per day. Against this background, the stipends that international tribunals provide the witnesses with (particularly to those of the prosecution) become a very compelling reason to join the witness ride for a while (or as long as possible). SCSL stipends come to 16,000 leones per day (approximately 5.25 dollars per day), but that is not all, SCSL also reimburses witnesses for food, lodging, and transportation; in the case of ICTR the stipends come to 22 dollars per day for protected witnesses and 110 dollars per day for non-protected ones. For its part, Sierra Leone features 0.03 doctors per one thousand people and the life expectancy for Sierra Leoneans is between 37 and 40 years of age, while Rwanda features 0.05 doctors per one thousand people, and the life expectancy for Rwandans is between 44 and 47 years of age. Again, against this background the services, such as medical care, that the international tribunals usually provide the witnesses with become a powerful incentive for engaging in witness activities (accuracy of the testimony is another matter). The ICTR, for instance, has set up its own clinic that even provides HIV treatment. Armoury states that this clinic provides treatment to more than two hundred witnesses (some of whom are seen on a weakly basis), and some witnesses who testified as far back as 1997 are still receiving care. ${ }^{81}$

c) Lies are to a certain extent, relatively easy to pull off at these international tribunals because basic facts that would serve to reveal those lies

\footnotetext{
${ }^{80} I d$. at 133 .

${ }^{81} I d$. at $135-148$.
} 
are difficult to be conclusively established: Regarding this issue, Combs points to a crucial expectation of an ordinary Western-style criminal procedure that is unfulfilled at the international level, which is that a thorough pre-trial independent investigation will be carried out both by the office of the prosecution and by defence counsel. We have alluded before to the problems surrounding investigations conducted by the office of the prosecution, so let us review Comb's observations regarding defence counsel investigations: The author refers to financial constraints, safety, and logistical concerns, and to political considerations, all of which impair primarily the defence counsel ability to undertake investigations. ${ }^{82}$

d) Virtual impunity for people engaged in perjury activities: Although Rule 91 of the ICTR Rules of Procedure grants the Trial Chambers the power to instruct the prosecutor to investigate allegations of witness perjury, the Trial Chambers have interpreted this rule in the sense of requiring from the one alleging an instance of perjury to prove the mens rea and actus rea regarding the witness concerned, as a previous condition to instruct the prosecution to start an investigation. This interpretation of Rule 91 renders the potential investigation useless because, what would be left to investigate if the movant has proven his perjury allegation already? In deed, ICTR Trial Chambers have only very recently ordered any investigations, and as Combs states, only when the witness confessed to perjury. ${ }^{83}$

\section{H. High Conviction Rates at these International Tribunals}

Now, given the quantity and nature of testimonial deficiencies (even when some of them could be explained by innocent-causes) we should expect a

${ }^{82}$ Regarding for instance, to financial constraints, the author refers to the Special Panels situation: The 6.3 million annual budget of the Panels was distributed among the prosecution and the salaries of the judges (6 million were allocated to the prosecution and the remaining 300 thousand to the judges). In this line, one of the Los Palos defence counsel said "we do not have witnesses, we wish we did," and complained that they lacked cars and time to travel to the districts, and that they also lacked resources to provide witnesses with transportation to Dili and to pay for their food and lodging while there. Regarding logistical difficulties, in some areas of Sierra Leone, roads are poor, impassable or nonexistent during the rainy season; and in some occasions in East Timor, given that vehicles were so scarce and travelling so hard, victims and perpetrators were transported to the court in the same car. Finally, regarding political considerations, in some cases defence counsel has maintained that the Rwandan government has harassed an intimidated defence witnesses in order to prevent them from testifying. But even if independent investigations were practical we have to keep in mind that Rwandan, Sierra Leonean, and East Timorese societies are non-documentary oral cultures, which means that the best these investigations can aspire to is to collect statements from more witnesses. See id.

${ }^{83}$ Id. at 201-203. 
huge amount of acquittals from these international tribunals. We could reasonably expect convictions to be the exception in this scenario. Nonetheless, convictions are the rule..$^{84}$

The question arising now is: How are Trial Chambers able to determine that the BARD standard has been met in this context of overwhelmingly problematic testimony (which is frequently the only kind of evidence available)? They do it, as Combs claims, by displaying a series of concealment tactics the overall purpose of which is to hide and burry the uncertain evidentiary foundations of their factual determinations in order to create the illusion of accurate fact-finding, and to convey a high level of certainty in their judgments (but being certain that $\mathrm{p}$ is not the same as being justified in believing that $\mathrm{p}) .^{85}$

\section{Trial Chambers' Attitude Towards Testimonial Deficiencies}

We turn now to the Trial Chambers' treatment of testimonial deficiencies outlined previously, to which Combs refers to as a lackadaisical attitude:

While at hearings the treatment of testimonial deficiencies amounts to the following:

a) Judges are inclined to unquestionably accept that testimonial difficulties (witnesses' reluctance to answer, vague testimony, inaccurate time, distance, and numerical estimations, and so on) are the product of educational and experiential limitations. This assumption plays such an important role that judges interject counsel questioning when they sense that the witness will not be able to respond even when the witness concerned has not given any indication not to understand certain terms or the whole question that she has been asked to answer. ${ }^{86}$

${ }^{84}$ Combs states that the SCSL is running a 100 percent conviction rate at present. Indeed, all eight defendants whose cases have been decided had received a conviction. The Special Panels are not that far away. They have acquitted only 3 of the 97 defendants whom they tried (97 conviction rate), but in 2 of the 3 acquittals the prosecutor recognized that he did not have sufficient basis for a conviction. Despite his attempt to withdraw the indictment before trial, the Trial Chamber did not accept it, nonetheless the Chamber did not have other option but to acquit in light of the fact that the prosecutor did not present the judges with any incriminatory evidence at all. For its part, the ICTR's conviction rate is at 85 percent, having acquitted six of its defendants. Armoury holds that three of these cases featured little or no credible evidence (so acquittals were assured), but in the remaining three, the acquittals seem to stem less from real differences in the quality and quantity of the testimony, than from the Trial Chamber's attitude (willingness to submit to a more rigorous scrutiny) towards the evidence. See id.

${ }^{85}$ Id. at 179 .

${ }^{86}$ For instance, in the RUF case at SCSL, when defence counsel asked a witness in what year certain killings had taken place, before giving the witness a change to answer, the Trial Chamber interjected by saying "you expect her to know the year?;" In the CDF case, judge 
b) At other times, judges tend to lose patience with defence counsel when they are pressing the respective witness to give information that would be particularly relevant to determine her credibility. Judges even seem not to understand the relevance pertaining to the witness's credibility of some questions that look to elicit information and details regarding for instance, to issues of time or to the witness's distance from a particular scene. $^{87}$

In Trial Chambers' judgments, the lackadaisical attitude has the following manifestations:

c) In general, judges fail to mention testimonial deficiencies in their judgments;

d) When they allude to testimonial deficiencies they tend to reduce or ameliorate their impact by using condescending and diplomatic phrases or by mischaracterizing witnesses' answers. ${ }^{88}$

e) In their judgments, judges often recourse to certain rhetorical techniques in order to refer to witnesses' testimony as if it did not feature inconsistencies. Nonetheless, that the testimony concerned featured inconsistencies becomes clear while reviewing the transcripts. ${ }^{89}$

Boutet admonished counsel to stop using the term "office of the prosecutor" by saying that "may be the witness does not understand what you mean by that" (again the witness did not give and indication that she was having any trouble to understand). Similarly judge Thompson intervened immediately when he heard the counsel asking "do you recall modifying that statement?" by saying "what is "modify" for him? Can't we be a little clear; otherwise we invite a kind of argumentative response." Id. at 189-203.

${ }^{87}$ In this line, in the Semanza case at the ICTR, when defence counsel was trying to determine the distance between a witness and a particular scene he was describing, judge Williams asked "where does this take us? Whether some people were three meters from him, or some people were five meters from him, or some people were ten meters from him, or some people are right up to him, how does all this help us?... How do all these little distances here and little distance there, and who is at the side, and who is in the front, how does that help us? See id.

${ }^{88}$ For instance in the $A F R C$ case, the Trial Chamber did acknowledge that witness TF1209 "had some difficulty in conveying what exactly she meant," and that her testimony "was at times unclear," but as Armoury states, these phrases failed to convey just how difficult it was for the lawyers and the Trial Chamber itself to get clear answers from the witness; for its part, in the $\mathcal{N}$ dindabahizi case, the Trial Chamber reported that witness CGV "gave a clear indication that the distance (between himself and the defendant) was about equal to the width of the courtroom," but again, while reviewing the respective transcripts Armoury was able to determine that it did not happen like that. As she explains, although initially witness GGV tried to estimate this distance by saying "from the wall on the other side" to "the other side of the room," his answer did not make it clear to lawyers and judges which walls he was precisely speaking of; and moreover, this witness eventually declined to estimate distance by either meters or courtroom references. See id.

${ }^{89}$ For instance, in the $C D F$ case, when witness TF2-152 testified inconsistently from his statement about which organs (the heart or the liver) the Kamajors cut out of his friend, the Trial Chamber reported simply in its judgment that "various organs were removed from TF2152's friend's torso;" Similarly, when witness TF2-154 testified inconsistently about how two 
f) Other occasions, when inconsistencies between testimonies and pre-trial statements do make their way to the judgments, the ICTR for instance, following Akayesu has the preference to give more probative value to in-court testimony on the grounds that the Trial Chambers generally do not have access to transcripts of the interviews from which the statements were drafted, which in turn makes them unable to consider the nature and form of the questions put to the witnesses, or the accuracy of the interpretation at the time; other reasons are that the statements were not made under solemn declaration and were not taken by judicial officers..$^{90}$ Sometimes the Trial Chambers have acknowledged that even in-court testimony has grave contradictions, nonetheless they credit other aspects of the testimony as though the serious mistake or false testimony is relevant only to the particular issue about which the witness erred or lied. But as we will see later, given that judges recourse to a style that seems to be recounting historical facts in which reference to testimony makes at best the footnotes of the judgment, the only way to know which aspects of a particular witness's testimony were considered grave mistakes or lies, and which weren't is by going through the transcripts. ${ }^{91}$

g) As it happened with most Special Panels cases and with all of the ICTR and SCSL cases, judges tend to write their judgments in a certain style where they seem to be recounting unquestionable historical facts by using a "comprehensive narrative." In doing this i) they sometimes make reference to defendant's words as if they were being quoted verbatim, but they do not explicitly make it clear that these words were being paraphrased by a witness who may be testifying lots of years after the atrocities took place; ii) they decline to articulate the substance of witnesses' testimony; iii) they decline to present the reader with the results of their testimony-evaluation task and with the justification for having reached such results; iv) Reference to witness testimony generally only appears as footnotes to the judgment; v) the testimony that contradicted the Trial Chamber's factual findings is not discussed (at least in a way that would contest the respective finding); vi) sometimes testimony that contests the Chamber's findings is alluded to but in a way that purports to give the impression that it is supportive testimony (by using see also cites); vii) the Chambers force the reader's confidence trying to assure her that they considered fully all the relevant testimony available including that which is at odds with its factual findings. Nonetheless the lack of

men were killed, the Trial Chamber avoided the issue and simply reported that "two men were killed." In the Kamuhanda case, when witness GEI testified inconsistently about which family members where with him when he fled his home, the Trial Chamber just reported that the witness "fled with his family". See id.

${ }^{90} I d$.

${ }^{91} I d$. 
reference to the latter is attempted to be justified by simply stating that it did not meet the threshold of reliability and credibility (who knows what that threshold is) to even make a factual conclusion upon it. ${ }^{92}$

h) Some other times, as in certain cases at the Special Panels, the Chambers decline to issue a conventional judgment and rather drafted a 3 or 4 page summary document that basically contains the crimes for which the defendant was convicted and the sentences that the Chamber imposed for those crimes. ${ }^{93}$

\section{J. Explaining the Pro-Conviction Bias}

Nancy Combs believes that international judges are, by and large, committed to the success of the international criminal law project and consequently they seek (may be even unconsciously) to take the necessary measures in order to ensure that the role and value of international tribunals will not get diminished. ${ }^{94}$

In this sense, they have to be (and they are) more open-minded and more sensitive to the opinions, perceptions, and potential actions that external actors - such as the usually large numbers of victims, the nation where the tribunals are established, or the international community as a whole (through the UN) - may engage in if they feel disappointed, which renders their activities, as they were described by Kingsley Moghalu, the former ICTR spokesperson, a kind of "political justice." "95

In deed politics underlies decisions such as where to set ad hoc international tribunals (why in Rwanda and Bosnia, and not in Russia or China? Armoury asks), and which people to indict once having dug deeper into the conflict (higher or middle level officials, or even politicians may be?), but it influences - though more indirectly - less macro-level features such as the attitude of judges towards testimonial deficiencies. ${ }^{96}$

The author maintains that at some level, international judges recognize that if they were to severely scrutinize the problematic testimony that they ordinarily receive and honestly acknowledged that it has the capacity to gravely undermine the prosecution's case, obviously they would have to issue acquittals in a far greater proportion. ${ }^{97}$

The problem is that acquittals are much more politically costly at the international level because it is likely that they will produce large-scale victim

\footnotetext{
${ }^{92} I d$.

${ }^{93} \mathrm{Id}$.

${ }^{94}$ ComBs, supra note 1, at 225-234.

${ }^{95} I d$.

${ }^{96} I d$.

${ }^{97} I d$.
} 
outrage which on its turn would impair the broader goal of reconciliation and peace-building in the land,$^{98}$ and could also lead to the withdrawal of enforcement and financial support of particular nations and of the international community as a whole (already long trials like ICTY's and ICTR's would be virtually impossible to justify if the money that could be spent in other post-atrocities measures, is used to set defendants free). In this line, Armoury believes that the "international community's continued support for international criminal trials is predicated on those trials resulting in convictions most of the time." ${ }^{\prime 9}$

\section{K. A Plausible Alternative Model for the Trial Chambers Action}

At this point of her research, Combs states the following: "I believe that most of the international criminal convictions are justified but on grounds different from those invoked in the Trial Chambers' judgments." ${ }^{100}$

But what are those other grounds that the above quotation indicates? To give us an answer the author presents us with a fact-finding model according to which judges only appear to be convicting solely for the charges in the indictments and basing their findings solely on the witness testimony that has been presented to them, but actually they supplement that problematic testimony with commonsense inferences from the defendant's official position or institutional affiliation in the context of the international crimes that have been committed; They overlook (or ameliorate the effect of) testimonial deficiencies based on the belief that any person who held the position that the defendant concerned held must have done "something" for which he should be held criminally responsible.

The problem of course is that these commonsense inferences are not expressly invoked by the Trial Chambers in their judgments; one can only make an educated conjecture (by thoroughly considering the information contained in the transcripts of the trials) that they are supplementing the reason-

${ }^{98}$ As Combs explains, the victims of international crimes, especially in African conflicts, will not see an acquittal in narrow legal terms as the unsuccessful attempt of the prosecutor to reach the BARD standard with the evidence presented at trial, but more broadly as a betrayal, as a denegation of their status as victims, and even as a negative to admit that massacres and atrocities took place. This outrage is exacerbated by the prosecutor's role itself within the proceedings. As a reflection of the notion that international tribunals are as accurate as public historical records of events, the prosecution has to establish the broader contours of the conflict by adducing background evidence regarding the existence of a wide-spread policy or a systematic attack against civilians or against particular groups. In this sense, victims are socialized little by little in the prosecution's theory of the case, which becomes even a heartconviction. See id.

${ }^{99}$ Id. at 233.

${ }^{100}$ Id. at 220. 
ing that leads them to make inculpatory factual findings with these kind of inferences. ${ }^{101}$

According to the fact-finding model previously outlined the specific acts that the defendants are charged with by the prosecutor in the respective indictments (such as that the defendant issued a particular set of orders in a particular time, that they planned the atrocities in particular meetings, that they encouraged violence by pronouncing a particular speech at a rally, that they distributed weapons to soldiers, or that they actually participated in the massacres being personally there and even having shot or wounded victims), become less important (not to the point of irrelevance as we will see later). The main focus of their fact-finding activities is on the defendants' broader (even unspecified) involvement in the violent episode for which judges sense that the defendants should ultimately be held criminally responsible.

They come to this general conclusion of the defendants' involvement in the atrocities by considering their official position or their institutional affiliation. The reasoning used is along the following lines:

The systematic, coordinated, wide-spread, and long-lasting nature of the violence that was unleashed gives us reasonable grounds to presume that the atrocities were carefully designed and planned in furtherance of (or pursuant to) a general policy or goal; The vast amount of resources deployed to execute the overall (criminal) purpose resembles to the kind of mobilization that a State, a State body or agency, or a State-like body is able to prepare, so it is reasonable to assume that a State or a State-like body or a collective entity was implicated; A State body or a State-like body usually works with an authoritative (or leadership) structure where different men hold different positions in order for the means to achieve the purpose to be coordinated from the top authoritative spheres to the bottom operative field-agents (or footsoldiers); So, if the defendant held a high-ranking influential position (not necessarily a military one) within the authoritative structure of the particular group or body to which he belongs (and it has been proven that that body or group doubtlessly participated in the atrocities), it is reasonable to presume that the defendant -considering his influence and ostensive power within his group or body- engaged in activities (actions or omissions) capable of making the criminal purpose to come into fruition.

\section{Plausible Motivations for the Implementation of a Surreptitious Fact-Finding Model}

Addressing why the Trial Chambers may have implemented this dual factfinding model in which formally they are basing their judgments solely on the consideration of problematic and deficient testimony (which nonetheless

${ }^{101}$ Id. at 215-236. 
is given the treatment of "good quality" evidence in the judgments), but surreptitiously and unofficially they recourse to commonsense inferences from the defendants' official positions and institutional affiliations, Combs points to the international community's general repudiation since Nuremberg, of criminal-attribution techniques such as organizational liability and of everything that bears any resemblance to the spectre of guilt by association. ${ }^{102}$

Nonetheless, Trial Chambers are not considering the membership condition only, the defendant has to have a role within the collective entity or group such that it is reasonable to presume that he could have engaged in activities (the ones he is charged with or others) that contributed to the emergence of an atmosphere suitable to promote the commission of international crimes. In this sense, we are talking about high-ranked officers or very influential individuals within the group's particular authoritative structure, not about any regular and ordinary member (such as a foot-soldier). In addition, there must be sufficient evidence to establish that the collective entity or the group concerned, as a whole, participated in the atrocities, and also some evidence - regardless of its defects - directly linking the defendant with the atrocities (which points, even when weakly, in the direction that the defendant concerned engaged in some specified acts, such as the issuing of orders, the pronouncing of a speech, or in some other acts which may locate the defendant closer and closer to the role of a physical perpetrator of the crimes himself).

But despite the fact that Trial Chambers are going beyond merely considering the defendant's membership in an organization, they do not dare to make their reasoning explicit, because allegedly that would bring a plethora of criticisms that could jeopardize the international criminal justice project's viability by questioning its legitimacy.

In this line, judges are caught in a sort of political and legal trap of pressures: As we have said, some of those pressures are external such as the international community's and the victims' desire to, and expectation that the tribunals will convict most of the time; other pressures come from within the legal community itself which by generally repudiating the use of associational doctrines and techniques to impose criminal liability ties the judges' hands and to a certain extent forces them to recourse to the implementation of unnatural fact-finding models such as the two-faced model we have referred to previously.

\section{ConCLUSION}

It is now well established that victims in general and victims of international crimes in particular have a right to know the truth of what happened. As Funk says,

\footnotetext{
${ }^{102}$ Id. at 237-239.
} 
...survivors of atrocity crimes, as well as the families and loved ones of those who were injured or murdered, want to know first and foremost who committed the crimes, and why the crimes were committed... Victims seek the truth because the truth, to some extent at least, alleviates their anguish, vindicates their status, encourages individual accountability, and has the potential of removing the perpetrators and their allies from power... [Establishing the truth] makes it more difficult for those accused to create fictionalized, self-serving accounts of what occurred. A proper understanding of the historic events, and even public outrage over the conduct that often took place in the public's name, can replace the twin dangers of complacency and resentment towards victims. ${ }^{103}$

Nonetheless, the truth-thwarting patterns outlined in this essay indicate that this right is plausibly being systematically violated as the International Community has implemented legal procedures, mechanisms, and practices that are much less reliable as truth-promoting or epistemic engines than what they purport to be.

Being aware of these patterns that undermine international criminal justice's ability to accurately determine the facts, and being willing to do something about them (by eradicating those patterns via making the legal frameworks and practices more susceptible to satisfy the epistemic principles outlined earlier) is our duty, one that will enable the International Community to pay its due respects and considerations to victims' concerns.

103 See Funk, supra note 2, at 127.

Recibido: 12 de octubre de 2011.

Aceptado para su publicación: 6 de abril de 2012. 